Bagenstos suggests that Justice Ginsburg's opinions for the Court display a particularly nuanced and responsive understanding of the disability rights movement's goals, an understanding that helps explain her effectiveness in achieving social change.

Finally, Professor Karst traces the history of a theory that would justify affirmative action, not as a remedy for specifically identifiable past discrimination, but looking forward, as a way to integrate the leadership of American institutions. Professor Karst highlights Justice Ginsburg's role in this theory's recent revival, with special attention to her opinions in the Adarand and Grutter cases.

\title{
RUTH BADER GINSBURG, PROFESSOR OF LAW
}

\author{
Herma Hill Kay*
}

\section{NTRODUCTION}

Ruth Bader Ginsburg was the nineteenth woman in the United States to be appointed a tenure or tenure-track member of the law faculty at a school that was approved by the ABA and a member of the Association of American Law Schools (AALS) when she became an assistant professor of law at Rutgers in 1963.' Nine years later, in 1972, she became Columbia's first tenured woman law professor. We are gathered here to celebrate an even more significant milestone of her career: the tenth anniversary of her appointment as the 107th Justice, the second woman Justice, and the first female Jewish Justice, ${ }^{2}$ of the United States Supreme Court. Other speakers will examine Justice Ginsburg's many significant

* Barbara Nachtrieb Armstrong Professor of Law, University of California, Berkeley School of Law; J.D., University of Chicago, 1959; B.A., Southern Methodist University, 1956.

1. See Herma Hill Kay, The Future of Women Law Professors, 77 lowa L. Rev. 5, 8-10 \& n.26 (1991) [hereinafter Kay, Future]. Unless otherwise indicated, the material presented in this section is drawn from my ongoing study of women law professors in the United States between 1900 and 2000. Except where otherwise noted, the AALS Directories of Law Teachers, published between 1922 and 2003, are the sources for the data presented in this paper concerning women law professors. My definition of a "professor" includes only tenure or tenure-track assistant, associate, and full professors who teach in the regular law school curriculum of a school approved by the ABA and a member of the AALS (ABA/AALS schools). See Kay, supra, at 9 n.20. This definition excludes librarians, clinicians appointed to a clinical track, adjunct professors, and legal writing teachers, even though some women law librarians have held and/or currently hold professorial titles.

2. See Ruth Bader Ginsburg, From Benjamin to Brandeis to Breyer: 1s There a Jewish Seat?, 41 Brandeis L.J. 229 (2002). Sec generally Malvina Halberstam, Ruth Bader Ginsburg: The First Jewish Woman on the United States Supreme Court, 19 Cardozo L. Rev. 1441 (1998). 
contributions as a jurist. With her help, ${ }^{3}$ I want to recall with you briefly her illustrious career as one of the nation's first women law professors.

\section{The Context}

Barbara Nachtrieb Armstrong, the first woman law professor at an ABA/AALS school, was appointed at Berkeley in $1919,{ }^{4}$ forty years before Ruth Bader Ginsburg graduated from Columbia in 1959. During those forty years, thirteen other women followed Armstrong into law teaching. These are the fourteen women I have called the "early women law professors" 5 of the twentieth century. By the time of Ginsburg's initial appointment at Rutgers in 1963, Armstrong had retired. Today, only one of the early women law professors-Minnette Massey at the University of Miami-continues to teach full time.

By 1972, when Ruth Ginsburg moved on to Columbia, women law professors were still rarities, but the long-standing practice of hiring only males to teach law was beginning to give way to the I970 AALS requirement that member schools refrain from "discrimination... on the ground of ... sex." 6 To their credit, Columbia and its peer schools were among the first to conform to the new standard. ${ }^{7}$ As shown in Table 1, all except one of the twelve schools rccently designated by Professor Richard K. Neumann, Jr., ${ }^{8}$ as "producer" schools-those most likely to train the law faculties of the future-had tenure or tenure-track women faculty by 1972. Although the appointments of women by these tweIve schools spanned a period of fifty-four years, only four occurred before 1960 .

3. Justice Ginsburg assisted in the preparation of this paper by verifying names, dates, and places that relate to her law teaching years and by providing me with unpublished material.

4. See Kay, Future, supra note 1, at 5-6.

5. See Herma Hill Kay, UC's Women Law Faculty, 36 U.C. Davis L. Rev. 331, 337, 405-06 (2003) [hereinafter Kay, UCl.

6. Committee Reports, 1970 Proc. Ass'n Am. L. Schs. (pt. 2) 76, 160 n.2 (recording amendment to Approved Association Policy). The amendment had been proposed by the newly created Special Committee on Women in Legal Education, of which one of the early women law professors, Ellen Peters of Yale, was a member. Special Committees, 1969 Proc. Ass'n Am. L. Schs. (pt. 2) 233, 234. Professor Ginsburg was appointed to the renamed 1971 Special Committee on Equality of Opportunity for Women in Legal Education. Special Committees, 1970 Proc. Ass'n Am. L. Schs. (pt. 2) 261, 261.

7. Measured by a different standard, however, their performance is less commendable. I have suggested elsewhere that the length of elapsed time between a law school's founding date and the date its first woman professor was hired serves as an indicator of the school's receptivity to women faculty. See Kay, UC, supra note 5, at 339 . Table 1 infra lists both relevant dates: Subtracting the woman's hiring date from the school's founding date gives a time lag for each of the twelve schools listed there ranging from a low of 25 years at Berkeley to a high of 155 years at Harvard, with Columbia showing a time lag of 115 years. 1d. at 351 tbl.I.

8. See Richard K. Neumann, Jr., Women in Legal Education: What the Statistics Show, 50 J. Legal Educ. 313, 318-19 \& tbl.4 (2000) (identifying twelve schools, based on their students' LSAT scores, "that appear likely to graduate a high proportion of the law faculties of the future"). 
Three schools appointed their first woman law professor between 1968 and 1971, while four-including Columbia-did so in 1972 and the twelfth followed suit in 1973. Table 1 also shows that six of these twelve schools hired a woman who had been their own graduate, a pattern common among the early women law professors as well. ${ }^{9}$ With one exception, each of the twelve graduated from a producer school-indeed, seven of them graduated from only tbree of these schools: two each from Columbia and Michigan and three from Yale. All but one of them became full professors. ${ }^{10}$ One, Soia Mentschikoff, became Dean at the University of Miami Law School in 1974. ${ }^{11}$ Two, including Justice Ginsburg, left academic life for judicial appointments. The four who remain active in law teaching today all hold named professorships.

Ruth had contacts with several of these women. She shared a boat trip on the Elbe and a long, pleasant conversation with Soia Mentschikoff in 1966 while both were attending a meeting of the International Association of Comparative Legal Studies at Hamburg. ${ }^{12}$ Ruth also recalls speaking with Soia about the recruitment of women faculty in 1973 when the latter was being installed as President-Elect of the Association of American Law Schools. Soia was concerned that law schools, in their haste to get "their woman" for the faculty would take women who were not the strongest candidates and then would say to later applicants, "We had a woman once, and she was unsuccessful." The solution to this problem, in Soia's view, was for the law schools to delay their recruitment of women faculty for about five years, when she believed that an abundant supply of "qualified" women would have graduated from law schools and become available for faculty positions. Ginsburg had not thought about the matter from Mentschikoff's perspective, but on reflection found much to be said for her view. ${ }^{13}$

Ruth met Betty Owens in 1972, and conferred with her about taking over a course on Women's Rights that Ruth had offered at Harvard. She

9. See Kay, UC, supra note 5, at 349-50.

10. The exception is Gail Starling Marshall of Virginia, who left teaching for practice in 1972. She joined the law firm of Hogan \& Hartson, becoming the firm's first female litigation partner. In 1986, she joined the staff of Virginia's first woman Attorney General, Mary Sue Terry, and initially headed up the Civil Litigation Division, later adding the Antitrust, Consumer Protection, Employment, and Opinions Divisions, and in her final year, the Criminal Litigation Division as well. She is currently Town Attorney for the Town of Orange. She told me that she feels "a little sorry for those who spend their entire careers in teaching and not doing." E-mail from Gail Marshall to Herma Hill Kay (July 9, 2003) (on file with the Columbia Law Review). Virginia's first tenured woman law professor, Lillian Riemer BeVier, a 1965 Stanford graduate, began her academic career as assistant professor at Santa Clara in 1970, visited at Virginia in 1973-1974, and was hired there in 1974. She became a full professor in 1978.

11. See Herma Hill Kay, Women Law School Deans: A Different Breed, or Just One of the Boys?, 14 Yale J.L. \& Feminism 219, 240 (2002).

12. Interview with Judge Ruth Bader Ginsburg in Washington, D.C. (Sept. 22, 1991) (transcript on file with the Columbia Law Review).

13. ld. 
Table 1. First Woman Appointed at Twelve "Producer" Schools By Appointment Date

\begin{tabular}{|c|c|c|c|c|}
\hline $\begin{array}{l}\text { School and } \\
\text { Founding Date }\end{array}$ & $\begin{array}{l}\text { Woman, Date, and Title of } \\
\text { Initial and Highest Rank }\end{array}$ & $\begin{array}{l}\text { School and } \\
\text { Date of } \\
\text { Law Degree } \\
\end{array}$ & $\begin{array}{l}\text { Prior Academic } \\
\text { Position, if Any, } \\
\text { and School }\end{array}$ & Current Status \\
\hline $\begin{array}{l}\text { Berkeley } \\
1894\end{array}$ & $\begin{array}{l}\text { Barbara Nachtrieb Armstrong } \\
\text { 1919, Instructor } \\
\text { (Professor, 1935) }\end{array}$ & \begin{tabular}{|l|l} 
Berkeley \\
1915
\end{tabular} & $\mathrm{~N} / \mathrm{A}$ & Deceased 1976 \\
\hline $\begin{array}{l}\text { Chicago } \\
1902\end{array}$ & $\begin{array}{l}\text { Soia Mentschikoff } \\
\text { 1951, Professorial Lecturer } \\
\text { (Professor, 1962) }\end{array}$ & $\begin{array}{l}\text { Columbia } \\
1937\end{array}$ & $\begin{array}{l}\text { Visiting Professor } \\
\text { 1947-1948, } \\
\text { Harvard Law } \\
\text { School } \\
\end{array}$ & Deceased 1984 \\
\hline $\begin{array}{l}\text { Yale } \\
1824\end{array}$ & $\begin{array}{l}\text { Ellen Ash Peters } \\
\text { 1956, Assistant Professor } \\
\text { (Professor, 1964) }\end{array}$ & $\begin{array}{l}\text { Yale } \\
1954\end{array}$ & $\mathrm{~N} / \mathrm{A}$ & $\begin{array}{l}\text { Chief Justice, } \\
\text { Ret., Connecticut } \\
\text { Supreme Court }\end{array}$ \\
\hline $\begin{array}{l}\text { Georgetown } \\
1870\end{array}$ & $\begin{array}{l}\text { Helen Elsie Steinbinder } \\
\text { 1957, Professor }\end{array}$ & \begin{tabular}{|l|} 
Georgetown \\
1955
\end{tabular} & $\begin{array}{l}\text { Research Law } \\
\text { Librarian } \\
1955-1957, \\
\text { Georgetown } \\
\end{array}$ & Retired 1988 \\
\hline $\begin{array}{l}\text { Virginia } \\
1826\end{array}$ & $\begin{array}{l}\text { Gail Starling Marshall } \\
\text { 1968, Instructor } \\
\text { (Assistant Professor, 1970) } \\
\end{array}$ & $\begin{array}{l}\text { Virginia } \\
1968\end{array}$ & $\mathrm{~N} / \mathrm{A}$ & Practice of Law \\
\hline $\begin{array}{l}\text { Pennsylvania } \\
1852\end{array}$ & $\begin{array}{l}\text { Martha A. Field } \\
\text { 1969, Assistant Professor } \\
\text { (Professor, 1976) }\end{array}$ & $\begin{array}{l}\text { Chicago } \\
1968\end{array}$ & $\mathrm{~N} / \mathrm{A}$ & $\begin{array}{l}\text { Langdell } \\
\text { Professor of Law, } \\
\text { Harvard Law } \\
\text { School } \\
\end{array}$ \\
\hline $\begin{array}{l}\text { New York } \\
\text { University } \\
1835\end{array}$ & $\begin{array}{l}\text { Linda J. Silberman } \\
\text { 1971, Assistant Professor } \\
\text { (Professor, 1982) }\end{array}$ & $\begin{array}{l}\text { Michigan } \\
1968\end{array}$ & $\mathrm{~N} / \mathrm{A}$ & \begin{tabular}{|l|} 
Martin Lipton \\
Professor of Law, \\
NYU
\end{tabular} \\
\hline $\begin{array}{l}\text { Columbia } \\
1857\end{array}$ & $\begin{array}{l}\text { Ruth Bader Ginsburg } \\
\text { 1972, Professor }\end{array}$ & $\begin{array}{l}\text { Columbia } \\
1959\end{array}$ & \begin{tabular}{|l|} 
Assistant \\
Professor 1963 \\
(Professor, 1969), \\
Rutgers (Newark) \\
\end{tabular} & \begin{tabular}{|l|} 
Associate Justice \\
U.S. Supreme \\
Court, 1993
\end{tabular} \\
\hline $\begin{array}{l}\text { Duke } \\
1930\end{array}$ & $\begin{array}{l}\text { Patricia H. Marschall } \\
\text { 1972, Professor }\end{array}$ & $\begin{array}{l}\text { Texas } \\
1955\end{array}$ & $\begin{array}{l}\text { Associate } \\
\text { Professor } 1969, \\
\text { Wayne State }\end{array}$ & $\begin{array}{l}\text { Retired 1992, } \\
\text { North Carolina } \\
\text { Central [now } \\
\text { Patricia H. } \\
\text { Spearman] } \\
\end{array}$ \\
\hline $\begin{array}{l}\text { Harvard } \\
1817\end{array}$ & $\begin{array}{l}\text { Elisabeth A. Owens } \\
\text { 1972, Professor }\end{array}$ & $\begin{array}{l}\text { Yale } \\
1951\end{array}$ & $\begin{array}{l}\text { Research } \\
\text { Assistant } \\
\text { 1955-1961, } \\
\text { Associate in Law } \\
\text { and Editor, } \\
\text { 1961-1963, } \\
\text { Lecturer in Law } \\
\text { 1963-1972, } \\
\text { Harvard Law } \\
\text { School } \\
\end{array}$ & Deceased 1998 \\
\hline $\begin{array}{l}\text { Stanford } \\
1893\end{array}$ & $\begin{array}{l}\text { Barbara Allen Babcock } \\
\text { 1972, Associate Professor } \\
\text { (Professor, 1976) } \\
\end{array}$ & $\begin{array}{l}\text { Yale } \\
1963\end{array}$ & N/A & $\begin{array}{l}\text { Judge John } \\
\text { Brown Professor } \\
\text { of Law, Stanford }\end{array}$ \\
\hline $\begin{array}{l}\text { Michigan } \\
1859\end{array}$ & $\begin{array}{l}\text { Christina Brooks Whitman } \\
\text { 1973, Assistant Professor } \\
\text { [began teaching 1976] } \\
\text { (Professor, 1982) }\end{array}$ & $\begin{array}{l}\text { Michigan } \\
1974\end{array}$ & N/A & $\begin{array}{l}\text { Francis A. Allen } \\
\text { Professor of Law, } \\
\text { Michigan }\end{array}$ \\
\hline
\end{tabular}


also knew Ellen Peters socially, but did not work with her closely until 1984, when Ellen joined Ruth as a member of the American Law 1nstitute Council, at a time after both had left academia to become judges. Ruth met Linda Silberman before Linda entered teaching while she was working as a research assistant at Michigan for Professor Arthur Miller. Both Ruth and Linda taught civil procedure, and Ruth had occasion to recommend Linda to a classmate as an expert witness. Barbara Babcock was an important supporter for both of Ruth's judicial appointments, first as head of the Civil Division of the U.S. Department of Justice and later as a Stanford professor. By 1980, when Ruth left Columbia to accept President Carter's appointment to the U.S. Court of Appeals for the District of Columbia Circuit, all of these twelve schools had added more women professors, and two of them-Georgetown and NYU-each had eight women on the faculty. ${ }^{14}$ Looking back in 1982 at her seventeen years as a law teacher, Ginsburg noted the increase in women faculty and also pointed to the corresponding growth in the number of women students during the period:

When I started in the law-teaching business in 1963, few women appeared on my seating charts, perhaps 5 or 6 in a class of over 100 . By 1980 , across the country, women comprised over onethird of total law-school enrollment, up from 3.6 percent in 1963 and 9.5 percent in 1971. In more than a few law schools today, 50 percent or more of the students are women. ${ }^{15}$

During the twenty-three years that Ruth Bader Ginsburg has served on the federal bench, the number and percent of women students has far outpaced that of women faculty. In fall 2002, the nation's 186 ABA-approved law schools enrolled 132,885 J.D. students of whom $65,179(49 \%)$ were women. ${ }^{16}$ While the exact number and percentage of women who qualify as law professors under the definition of that term set out above ${ }^{17}$ still requires refinement, the Office of the Consultant on Legal Education to the ABA puts the number of full-time women faculty as of fall 2002 at 2467 , or $35 \%$ of the total. ${ }^{18} 1$ turn now to an examination of Ruth Bader Ginsburg's role in that history of women in academic law, drawn in part

14. Ass'n of American Law Schools, Directory of Law Teachers, 1980-81, at 58-59 (Berkeley), 63-64 (Chicago), 65-66 (Columbia), 73 (Duke), 76-78 (Georgetown), 81-82 (Harvard), 96-97 (Michigan), 103-05 (NYU), 111 (Pennsylvania), 122-23 (Stanford), 130-32 (Virginia), 137-38 (Yale) (1981). Columbia added three women as assistant professors in 1981. Ass'n of American Law Schools, Directory of Law Teachers 36-37 (Supp. 1981-1982).

15. Ruth Bader Ginsburg, Women's Work: The Place of Women in Law Schools, $32 \mathrm{~J}$. Legal Educ. 272, 272 (1982) (citing Donna Fossum, Women Law Professors, 1980 Am. B. Found. Res. J. 903).

16. E-mail from David Rosenlieb, Data Specialist, Office of the Consultant on Legal Education and Admissions to the Bar, to Herma Hill Kay (July 21, 2003) (on file with the Columbia Law Review) (reporting that 2001 statistics were 127,610 J.D. students and 62,476 women, or $48.9 \%$ ).

17. See supra note 1 .

18. E-mail from David Rosenlieb, supra note 16. 
from her own writings as well as her recollections expressed in her unpublished and informal talks about her career.

\section{The Beginning: Legal Education, Clerkship, First Job}

Born in Brooklyn on March 15, 1933 to Jewish Americans whose families had immigrated from Central Europe and Russia, Ruth credits her mother, Celia Bader, for encouraging her intellectual development. ${ }^{19}$ Ruth graduated from Cornell University in 1954, where she was ranked first among the women in her class and was elected a member of Phi Beta Kappa. At Cornell, she earned a B.A. with a major in Government and made two of her life's most important choices: a career and a husband. On June 23, 1954, she married Martin D. Ginsburg, who had graduated from Cornell the preceding year. While at Cornell, they both decided to become lawyers. Marty was called into military service after completing his first year at Harvard Law School. The couple spent the next two years at Fort Sill, Oklahoma. Marty served as an instructor in the artillery school while Ruth worked as a clerk in the Lawton, OkIahoma Social Security office. Their daughter, Jane Carol Ginsburg, was born on July 21, 1955. Marty resumed his studies at Harvard Law School as a $2 \mathrm{~L}$ in the fall of 1956 and Ruth entered Harvard that same year.

Harvard Law School did not admit women as students until 1950.20 In 1956 Harvard had an entering first year class of 552 students, including nine women." Ruth recalled her feelings: "We had nine women in our class and all the professors knew us. If you're a woman nowadays, you're not something special, you're not a freak. Then you were so much more conscious of your special place."22 In 1956, there were no women on the Harvard faculty. Soia Mentschikoff, the first woman to teach law at Harvard, had come and gone before Ruth and Marty arrived. ${ }^{23}$ Elisabeth

19. Edith Lampson Roberts, Ruth Bader Ginsburg, in The Supreme Court Justices: Illustrated Biographies, 1789-1995, at 531, 531-32 (Clare Cushman ed., 2d. ed. 1995).

20. Erwin N. Griswold, Ould Fields, New Corne: The Personal Memoirs of a Twentieth Century Lawyer 171 (1992) (reporting that the vote in favor of admitting women was "about three to one"). The yearbook of the class of 1953 featured a drawing of a baby carriage with an attached sign reading "Portia Glutz Atty-at-Law Harvard '53." The Harvard Law School Yearbook 28-29 (1953).

21. See Alumni Directory of the Harvard Law School, The Quinquennial Catalogne, Chronological Section, at 116-19 (1963). The class listings have two separate columns: one for Harvard Law School graduates, and another for "Non-Graduates." The latter are students who enrolled at Harvard but did not take a degree there. The name of "Ruth Joan Ginsburg" appears in the non-graduate list of the Class of 1959. Id. at 119.

22. Ruth Bader Ginsburg, The Equal Rights Amendment Is the Way, 1 Harv. Women's L.J. 19, 20 (1978) [hereinafter Ginsburg, ERA the Way] (editors' introduction).

23. See Ass'n of American Law Schools, Directory of Teachers in Member Schools 1947-1948, at 12 (continued as AALS Directory of Law Teachers) (listing Soia Mentschikoff as a Visiting Lecturer at Harvard Law School for academic year 1947-1948); Ass'n of American Law Schools, Directory of Teachers in Member Schools 1948-1949, at 4 (listing Soia Mentschikoff as a Visiting Professor for 1948-1949). Judith Richards Hope reports that Mentschikoff's appointment "was a great success and had an unexpected benefit: she 
A. Owens, Harvard's first tenured woman law professor, had been in residence at the school since 1955 as a Research Assistant to Professor Stanley Surrey in the international tax program following her graduation from Yale Law School in 1951 and four years of practice with a Boston law firm. ${ }^{24}$ Neither of the Ginsburgs had any contact with Owens while they were Harvard students, perhaps because she was not at that point a member of the Harvard faculty and did not teach in the regular program. ${ }^{25}$

Ruth spent only two years at Harvard. Her time there was not only busy-both parents shared the responsibility of raising their daughter while studying-but also academically successful. She was an excellent student who was elected to the Harvard Law Review. ${ }^{26}$ With the other first-year women students, she attended the reception Dean Griswold gave for them and vividly remembers his asking each guest to tell him her reasons for occupying a place in the class that would otherwise have gone to a man. Writing his own memoirs years later, Griswold confided that he was somewhat surprised to learn that the women students did not appreciate his questioning:

To my regret, I now find that these questions-though purely factual in intent-were resented, and that they are now recalled by some women graduates as examples of sexism on my part. That was really far from my intention. I was trying, if anything, to encourage the women to make full use of their legal training, in practice or in service, of varying kinds, to the public. ${ }^{27}$

During Ruth's second year, Marty contracted cancer, a condition that necessitated massive surgery, followed by weeks of radiation treatments. ${ }^{28}$ She arranged for note takers among his classmates and typed his third year paper, ${ }^{29}$ which he dictated in installments over several evenings. He returned to class for the last two weeks of the spring semester and graduated in 1958 with his class. He then accepted a job as the seventeenth lawyer engaged by the New York City firm of Weil, Gotshal \& Manges. Not wishing to remain in Cambridge as a single mom, Ruth applied to Harvard for permission to spend her last year at Columbia in

single-handedly integrated the Harvard Faculty Club." Judith Richards Hope, Pinstripes and Pearls: The Women of the Harvard Law School Class of '64 Who Forged an Old-Girl Network and Paved the Way for Future Generations 15 (2003) (quoting Harvard Professor Louis Toepfer).

24. See Ass'n of American Law Schools, Directory of Law Teachers, 1973, at 32 (1972) (listing Elisabeth Owens as Professor of Law at Harvard University Law School).

25. See Herma Hill Kay, In Memoriam: Elisabeth A. Owens, 112 Harv. L. Rev. 1403, 1404 (1999) [hereinafter Kay, Owens] (discussing Owens's career at Harvard); see also Joel Seligman, The High Citadel: The Influence of Harvard Law School 128 (1978) (noting with apparent sarcasm that "Owens, associated with the Law School for seventeen years as a researcher and lecturer, was suddenly found to be 'professorial' material and received a full professorship effective July 1, 1972").

26. See Harvard Law Review Masthead, 71 Harv. L. Rev. 325 (1957).

27. Griswold, supra note 20 , at $173-74$.

28. Roberts, supra note 19 , at 532 .

29. Id. 
satisfaction of her Harvard degree. Her good friend, Professor Gerald Gunther, related what came next:

Her application was denied by the Dean: she was told that she had not made out an adequate case of exigent personal circumstances required for such permission. Her understandable desire that she and her young child reside in the same location as her husband proved to be an insufficient ground, even though to my knowledge applications by males for similar permissions were quite frequently granted. ${ }^{30}$

Ruth thereupon moved to New York and entered Columbia Law School, with full credit given for her two years at Harvard. She recalled, gratefully, that unlike Dean Griswold, "Dean Warren didn't ask any questions. He just accepted me." 31 At Columbia, as at Harvard, she was elected to the Law Review ${ }^{32}$ and excelled academically: She graduated tied for first place in the Class of 1959. And at Columbia, as at Harvard, there were no women law professors who might have served as her role models and mentors. Instead, she was mentored by several male teachers at Columbia who were generous-and unusual-enough to take an interest in her career. Gunther, who recalled her as being a "petite, attractive, earnest, and obviously brilliant young woman," 33 has recounted that he secured her clerkship with District Court Judge Edmund L. Palmieri after overcoming the Judge's reluctance to hire a woman clerk, particularly one with a young child, by guaranteeing him a male backup as a replacement should he be unable to work with her, and threatening to cut off the Judge's future supply of Columbia clerks should he be unwise enough to refuse to give her a "trial run." ${ }^{4}$ Ruth, who recognized that "her status as 'a woman, a Jew, and a mother to boot' was 'a bit much' for prospective employers in those days," 35 was grateful for the opportunity.

Some years after her graduation from Columbia, Ruth recalled that Harvard "finally thought me worthy of a degree." 36 Her response to the offer extended by Dean Albert Sacks in 1971, which conditioned the grant of a Harvard diploma upon her renunciation of her Columbia degree, was swift and unequivocal: " 1 hold only one earned law degree. It is from Columbia. I treasure it and will have no other." 37

Following her two year clerkship with Palmieri, another mentor appeared. Hans Smit, a 1958 Columbia graduate, had returned to the school in 1960 as the founding director of its Project on International

30. Gerald Gunther, Ruth Bader Ginsburg: A Personal, Very Fond Tribute, 20 U.

Haw. L. Rev. 583, 583 (1998).

31. Justice Ruth Bader Ginsburg '59, Columbia Law School Report, Spring 1994, at 9.

32. See Columbia Law Review Masthead, 59 Colum. L. Rev. 152 (1959).

33. Gunther, supra note 30 , at 583 .

34. 1d. at 584 .

35. Roberts, supra note 19 , at $\mathbf{5 3 2}$.

36. Ruth Bader Ginsburg, Remarks for Columbia University Reception (June 21, 1994) (on file with the Columbia Law Review) [hereinafter Ginsburg, Remarks].

37. Id. 
Procedure. He hired Ginsburg in 1961 to work on the project for two years. She served as a research associate on the project in 1961-1962, and as its associate director in 1962-1963. She has described Smit's profound influence on her as a scholar and teacher:

In those days I was rather diffident, modest, and shy. Hans was the ideal person to help me overcome those traits. He encouraged me to speak in public, to write for law journals, even to take over his civil procedure class for a week. . . .

Hans brought me into the comparative law circuit starting in the early $1960 \mathrm{~s}$, influencing my perspective on legal issues ever after, and advancing my appreciation of fine food and wine. ${ }^{38}$

During her work on this project, Ruth undertook a study of Swedish civil procedure together with Anders Bruzelius, a City Court judge in Lund, Sweden. Their joint effort was published as a book in $1965 .{ }^{39}$ Four years later, in recognition of this work, the co-authors received honorary degrees from the University of Lund. In 1963, Smit became Professor of Law at Columbia. That same year, Associate Director Ruth Bader Ginsburg became Assistant Professor Ginsburg at Rutgers Law School-a post she credits Columbia Professor Walter Gellhorn for being instrumental in having arranged. ${ }^{40}$

\section{I11. First ACademic Appointment: Rutgers Law School, 1963-1972}

At Rutgers, Ginsburg had the luxury of joining a law faculty where another woman law professor-Eva Hanks-was already in residence. In 1963, only two other law schools had two women serving together: the University of Miami, with Jeanette Ozanne Smith and Maria Minnette Massey, and Howard University, with Alessandra del Russo and Patricia Roberts Harris. ${ }^{41}$ Ginsburg found Hanks a source of great support:

38. Ruth Bader Ginsburg, Introduction of Hans Smit, Columbia Law School Washington, D.C. Alumni Association Dinner (May 10, 2001) (on file with the Columbia Law Review).

39. Ruth Bader Ginsburg \& Anders Bruzelius, Civil Procedure in Sweden (1965). Articles by Ginsburg based on the study include The Jury and the Namnd: Some Observations on Judicial Control of Lay Triers in Civil Proceedings in the United States and Sweden, 48 Cornell L.Q. 253 (1963), and Civil Procedure: Basic Features of the Swedish System, 14 Am. J. Comp. L. 336 (1965).

40. Ruth Bader Ginsburg, Remarks for First Meeting of Alumnae of Columbia Law School (Mar. 11, 1996) (on file with the Columbia Law Review). Because she was hired to replace Clyde Ferguson, who had left Rutgers to become Dean at Howard University Law School, Ginsburg later told a Columbia Law student reporter "that the school might have said, 'If we can't get a black to replace Clyde, let's get a woman." Mitchel Ostrer, Columbia's Gem of the Motion: A Profile of Ruth Bader Ginsburg, Juris Dr., Oct. 1977, at 34,36 .

41. See Kay, Future, supra note 1, at 8-10 \& n.26 (chronicling the "slow but steady" entry of women professors after 1945). Jeanette Smith began teaching at Miami in 1949, while Minnette Massey started there as a law librarian in 1951 and moved to full-time law teaching in 1958. Both are among the fourteen early women law professors. Alessandra 
Rutgers was surely ahead of the pack, for 1 was the second woman to be hired as a law teacher at this school. Eva Hanks was the first. She came on board the year before, in 1962. She was a great and good friend, tipping me off to the ways of the Brethren here, much as Sandra Day O'Connor did when 1 was new on the Supreme Court. ${ }^{42}$

During her first three years in law teaching, from 1963-1966, Assistant Professor Ginsburg was able to develop her scholarly interest in civil procedure by teaching three courses in the area: Remedies, Civil Procedure, and a Comparative Procedure Seminar, which focused on Swedish civil procedure. Her publications during this period were devoted to the same field. ${ }^{43}$ She also contributed chapters on the Scandinavian countries (with co-authors) to a book on international judicial assistance edited by Hans Smit.44

Ruth's international and comparative law work at Rutgers brought her some key assignments in national organizations. She was named to the Editorial Board of the American Journal of Comparative Law in 1966, to the European Law Committee of the American Bar Association's Section of International Law and Practice in 1967, and to the Board of Directors of the American Foreign Law Association in 1970.

Based on this substantial record of publication, teaching, and professional service, Ginsburg was promoted to associate professor in 1966. In that year, she added the basic Comparative Law course to her teaching regime, as well as courses in Conflict of Laws and Federal Jurisdiction. The year 1968 saw publication of her translation, also co-authored with Bruzelius, of the Swedish Code of Judicial Procedure, ${ }^{45}$ which encompassed both criminal and civil procedure. Associate Professor Ginsburg

del Russo began teaching at Howard in 1961, while Patricia Roberts Harris joined her as an assistant professor in 1963. See Ass'n of American Law Schools, Directory of Law Teachers in American Bar Association Approved Law Schools, 1963, at 32 (1962). When I joined the Berkeley faculty in 1960, Barbara Armstrong was still in residence updating her family law treatise. Although she was my invaluable mentor, she had retired in 1957.

42. Ruth Bader Ginsburg, Remarks for Rutgers (Apr. 11, 1995) (on file with the Columbia Law Review) [hereinafter Ginsburg, Remarks for Rutgers].

43. See, e.g., Ruth B. Ginsburg, Special Findings and Jury Unanimity in the Federal Courts, 65 Colum. L. Rev. 256 (1965); Ruth B. Ginsburg, The Competent Court in Private International Law, 20 Rutgers L. Rev. 89 (1965).

44. Arthur Boström, Anders Bruzelius, Ormonde Goldie \& Ruth B. Ginsburg, International Co-operation in Litigation: Sweden, in International Co-operation in Litigation: Europe 332 (Hans Smit ed., 1965) [hereinafter International Co-operation]; Feodor Nielsen \& Ruth B. Ginsburg, International Co-operation in Litigation: Denmark, in International Co-operation, supra, at 52; Frode Ringdal, Gunnar Vefling \& Ruth B. Ginsburg, International Co-operation in Litigation: Norway, in International Cooperation, supra, at 281; Voitto Saario \& Ruth B. Ginsburg, International Co-operation in Litigation: Finland, in 1nternational Co-operation, supra, at 105.

45. Swedish Code of Judicial Procedure (Anders Bruzelius \& Ruth Bader Ginsburg trans., 1968). 
published her still-classic tenure article on Full Faith and Credit in $1969^{46}$ and was promoted to full professor the next year.

ln a stunning reversal of field following her promotion, Professor Ruth Bader Ginsburg never published another major article on civil procedure after $1970 .{ }^{47}$ Instead, beginning in 1971, she focused her energies and scholarly attention on the legal status of women. Two external events appear to have sparked this change of direction. Looking back on this period in 1995, she thus described these events in a talk given at Rutgers:

Around 1970, women students whose conscience had awakened at least as much as mine, women encouraged by a vibrant movement for racial equality, asked for a seminar on Women and the Law. I repaired to the Library. There, in the space of a month, I read every federal decision ever published involving women's legal status, and every law review article. That was no grand feat. There were not many decisions, and not much in the way of commentary. Probably less altogether than today accumulates in six months time.

I was engaged in preparing materials for the seminar when Frank Askin had a visitor in his constitutional law class or constitutional litigation seminar. The visitor was Mel Wulf, then Legal Director of ACLU's National Office. The Supreme Court had just noted probable jurisdiction in a case called Reed v. Reed. The complainant, Sally Reed, had challenged an Idaho statute that read: As between persons "equally entitled to administer" a decedent's estate, "males must be preferred to females." The ACLU had filed the Jurisdictional Statement in Reed and I asked Mel if I could write the Brief for Appellant. We will write the brief, Mel said, and so we did, Mel and I together, with the grand aid of students from Yale, NYU, and Rutgers. ${ }^{48}$

Her own personal experience of encountering sex-based obstacles to her progress in the legal profession no doubt also played an important role in her newly-expressed interest in securing legal equality between men and women. She told a gathering at Rutgers that she was paid less than her male colleagues upon joining the faculty there in 1963:

46. Ruth B. Ginsburg, Judgments in Search of Full Faith and Credit: The Last-inTime Rule for Conflicting Judgments, 82 Harv. L. Rev. 798 (1969) (clarifying the priority to be accorded to inconsistent final state court judgments).

47. Her resume lists several brief pieces, all concerned with international aspects of the subject, see, e.g., Ruth Bader Ginsburg, Recognition and Execution of Foreign Civil Judgments and Arbitration Awards, in Legal Thought in the United States of America Under Contemporary Pressures 237 (John N. Hazard \& Wenceslas J. Wagner eds., 1970); Rutb Bader Ginsburg, Recognition and Enforcement of Foreign Civil Judgments: A Summary View of the Situation in the United States, 4 int'l Law. 720 (1970), and several notes in volumes 3, 4, and 6 of the International Lazyer, all relating to Scandinavian systems, see, e.g., Benjamin Busch \& Ruth Bader Ginsburg, Summary Adjudication: Sweden, 4 Int'l Law. 882 (1970); Ruth Bader Ginsburg, The Availability of Legal Services to Poor People and People of Limited Means in Foreign Systems, 6 Int'l Law. 128 (1972).

48. Ginsburg, Remarks for Rutgers, supra note 42. 
Dean Willard Heckel, one of the kindest, finest men I have ever known, carefully explained about the State University's limited resources, and then added it was only fair to pay me modestly, because my husband had a very good job. ${ }^{49}$

The Dean's frankness was somewhat surprising, considering that the Equal Pay Act became effective in 1963, the year Ginsburg was hired. She added that "[s]ome seven years later, I was part of a class of women from all faculties at Rutgers, Newark, each of whom received an enormous raise in settlement of an Equal Pay claim." 50 In addition to unequal pay, she initially lacked job security at Rutgers and instead had a contract that was renewed annually. When she became pregnant during her second year of teaching, she feared that her contract would not be renewed for a third year if she revealed her condition. Her fear may have stemmed from the fact that when her first child was born, "it was understood that I would leave work and not come back." ${ }^{51}$ She developed an effective strategy to conceal her pregnancy: "I said nothing, but borrowed clothes from my ever supportive, one size larger mother-in-law. With her wardrobe at my disposal, I managed to make it through the spring semester." ${ }^{2}$ Once the contract was signed, Ginsburg felt free to announce the good news that she was expecting a second child to a few of her colleagues. Her son, James Steven Ginsburg, was born on September 8, 1965.

Ginsburg first taught a course entitled Women's Rights: Sex Discrimination and the Law at Rutgers in 1970-1971 and again in 1971-1972 along with her regular offerings on Civil Procedure and Conflict of Laws. The AALS Directory listed her as a lecturer at Harvard Law School in 1971-1972 but did not list the name of the course she was to teach. The course was Harvard's first offering on women's rights, and Ginsburg commuted from New York to teach it in the fall semester of 1971. She was invited to continue during the spring semester but, growing tired of the commute and having accepted Columbia's offer of a tenured professorship, she declined. Dean Albert Sacks prevailed upon Elisabeth Owens to teach the course in spring 1972.53 Ginsburg and Owens met for the first time when they conferred about the course that Owens-an expert in international tax who was unfamiliar with the subject of women's rightswould teach. ${ }^{54}$

Ginsburg published her first two law review articles on women's rights in 1971 while still at Rutgers: The first criticized the meager coverage of the subject in law school and was part of an early symposium on

49. Id.

50. Id.

5I. Id.

52. Id.

53. See Kay, Owens, supra note 25, at $\mathbf{1 4 0 7 .}$

54. Interview with Judge Ruth Bader Ginsburg, supra note 12. 
the status of women; ${ }^{55}$ the second examined constitutional aspects of the topic. ${ }^{56}$ In 1972, she returned to her alma mater to join the Columbia faculty as Professor of Law.

\section{Ginsburg at Columbia: Teacher, Scholar, Activist}

In 1972, the year Ruth Bader Ginsburg joined the Columbia faculty, Title VII of the Civil Rights Act of 1964 was extended to cover university employment practices. ${ }^{57}$ Thereafter, a law school's refusal to hire an otherwise qualified woman to teach law because of her sex was not only an infraction of AALS membership requirements, ${ }^{58}$ but also a violation of federal law. ${ }^{59}$ Ruth recalls that the circumstances of her appointment as Columbia's first tenured woman law professor were remarkably low-key: "1 was not subjected to any examination or asked to show and tell. The faculty simply held a cocktail party in my honor to say welcome home."

Ruth may have experienced her return to Columbia as uneventful, but her new dean, Michael Sovern, reportedly expressed "glee" in an interview about the school's success in recruiting her to its faculty, in part because of her "distinguished" scholarship ${ }^{61}$ but also, in the reporter's view, because the school had beaten out some of its rivals in hiring her. ${ }^{62}$ In any event, Ginsburg's new colleagues soon discovered that they had

55. Ruth Bader Ginsburg, Treatment of Women by the Law: Awakening Consciousness in the Law Schools, 5 Val. U. L. Rev. 480 (1971).

56. Ruth Bader Ginsburg, Sex and Unequal Protection: Men and Women as Victims, Speech Before the Southern Regional Conference of the National Conference of Law Women (Oct. 1, 1971), in 11 J. Fam. L. 347 (1971).

57. Equal Employment Opportunity Act of 1972 § 3, Pub. L. No. 92-261, 86 Stat. 103, 103-04 (codified as amended at 42 U.S.C. $\$ 2000 \mathrm{e}-1$ (a) (2000)).

58. See supra note 6 and accompanying text.

59. This sequence of events may help explain Soia Mentschikoff's concerns expressed to Ruth Bader Ginsburg in 1973 that law schools were so anxious to hire "their woman" faculty member that they were not paying sufficient attention to the qualifications of the candidates. See supra text accompanying note 13 .

60. Ginsburg, Remarks, supra note 36.

61. See Lesley Oelsner, Columbia Law Snares a Prize in the Quest for Women Professors, N.Y. Times, Jan. 26, 1972, at 39 (reporting that "[i]n a new accelerating competition among the nation's law schools, Columbia University has just scored a major coup: its law school, to its undisguised glee, has just bid for and won a woman for the job of full professor-the first in its 114-year history," and going on to note that "[ $t$ ] he glee comes in part because the woman, Ruth Bader Ginsburg, is what the school's dean, Michael Sovern, calls 'so distinguished a scholar,' that her credentials and honors would stand out in any catalogue of professors").

62. Id. Oelsner noted that Ginsburg's appointment came

[a]s the University of Michigan Law School dean, Theodore St. Antoine, says, at a time when many of the country's best law schools have been "scrambling" for women, often for the same one. Most have no women at any rung of the professorial ladder, and, according to other sources, the woman Columbia got was among those being scrambled for.

Id. 
welcomed an activist into their midst. As she said in 1994 at a Columbia reception:

My very first month on campus, Columbia sought to save money in the housekeeping department. The University sent lay off notices to 25 maids-and no janitors. I entered that fray, which happily ended with no lay offs. I also supported (as the Law School's representative to the University Senate) the request of the campus Commission on the Status of Women for a comprehensive equal pay salary review.

Hardest for my University and Law School colleagues to bear was the litigation that followed a tea Madame $\mathrm{Wu}$, a worldrenowned physics professor, held at her Claremont Avenue apartment on a clear winter day, for all the senior women at Columbia. (Eleven women had achieved that rank in the mid1970s, compared to over one thousand men.) One of the eleven, Carol Meyer, Professor at the School of Social Work, wrote about the meeting years later. ${ }^{63}$ She was more than a little suspicious when she received the invitation, which came from me. "Women meeting together? Was this to be a cell meeting of some kind," she wondered. What we discussed was the sex differential then part of the University's TIAA-CREF plan, under which women received lower monthly retirement benefits because, on average, women live longer than men. Eventually, a federal case was filed, with some one hundred Columbia women-teachers and administrators-as named plaintiffs. . . In that matter, as in many others-I recall particularly an earlier episode involving a request to extend health benefits to cover pregnant employees-I was shielded from accusations of disloyalty to the University by law school deans (first Michael Sovern, then Albert Rosenthal) and colleagues who-although they did not inevitably agree with me on the merits-recognized the value of having the questions fully aired. ${ }^{64}$

During each of her eight years of teaching at Columbia, Ruth consistently offered her course on Women's Rights: Sex Discrimination and the Law. Between 1972 and 1974, she collaborated with Kenneth M. Davidson of SUNY Buffalo and me in editing the first casebook on sex-based discrimination, ${ }^{65}$ published in $1974 .{ }^{66}$ Thereafter, she used this casebook for her courses. Typically she also offered courses on Civil Procedure and

63. See Carol H. Meyer, The First Activist Feminist I Ever Met, 9 Affilia 85, 85 (1994) (" 1 also have a strong memory of Ginsburg-a diminutive woman with black hair, tied with a huge bow. Ginsburg was gracious and funny and clearly in command as she told us her purpose for bringing us together.").

64. See Ginsburg, Remarks, supra note 36.

65. See Linda K. Kerber, Writing Our Own Rare Books, 14 Yale J.L. \& Feminism 429, 430-31 (2002). Professor Kerber notes that the first monograph on the topic was published in 1969 by Professor Leo Kanowitz under the title Women and the Law: The Unfinished Revolution (1969). Kerber, supra, at 429.

66. Kenneth M. Davidson, Ruth Bader Ginsburg \& Herma Hill Kay, Text, Cases and 
Conflict of Laws, adding Constitutional Law in her final two years. She dropped Remedies and Comparative Law, although these courses continued to be listed under her name in the AALS Directories.

Following her Columbia appointment, Ginsburg was chosen for leadership positions in several national organizations. She was named to the AALS Executive Committee in 1972, filling out the term of her new Columbia colleague, Professor Maurice Rosenberg, who became AALS President-Elect in that year; to the Board of Editors of the ABA Journal in 1972; as Vice President of the American Foreign Law Association in 1973; to the Board of Governors of the Society of American Law Teachers in 1975, and as its Vice President in 1978; to the Council of the American Law Institute in 1978; as Vice President of the Federal Bar Council in 1978; and to the Board of Directors of the American Bar Foundation in 1979. She also served as a member of the Executive Committee of the Association of the Bar of the City of New York from 1974 to 1978, and thereafter on its Civil Rights Committee and its Sex and Law Committee.

Ruth Bader Ginsburg did her most significant law reform work at Columbia. Like some of the early women law professors before her, ${ }^{67}$ she melded her teaching, scholarship, and advocacy in the service of a cause that engaged her completely for the remainder of her academic career. ${ }^{68}$ Her cause was a grand one: to put women into the United States Constitution, and thereby, as she put it, "to help place women's rights permanently on the human rights agenda." 69 To achieve this goal, she explored two avenues simultaneously, one direct, the other indirect. The

Materials on Sex-Based Discrimination (1974). The Authors' Note and Acknowledgments thus describes the division of labor:

Kenneth M. Davidson is responsible for Chapter III (Women and Employment) and Chapter V (A Glance at Normative Aspects of the Criminal Law in Delineating Sex Roles). Ruth Bader Ginsburg authored Chapter I (Constitutional Aspects), Chapter IV (Educational Opportunity) and Chapter VI (Comparative Side-Glances). Herma Hill Kay wrote Chapter II (Sexual Interaction Within Family Life).

Id. at xv. In 1970, Davidson was teaching a survey course on sex discrimination in employment and he had prepared a draft manuscript on that topic. See Ruth Bader Ginsburg, Treatment of Women by the Law: Awakening Consciousness in the Law Schools, 5 Val. U. L. Rev. 480, 480 n.4 (1971). After the work was finished, the co-authors showed their commitment to equality between the sexes by their insistence on listing their names in alphabetical order, despite the advice of Roger Noreen, West's Law School Division Editor, that sales might be improved by listing one of the women as lead author.

67. For example, Barbara Nachtrieb Armstrong worked on social insurance, see Barbara Nachtrieb Armstrong, Insuring the Essentials: Minimum Wage Plus Social Insurance-A Living Wage Program (1932), and Soia Mentschikoff helped prepare and implement enactment of the Uniform Commercial Code, see Soia Mentschikoff, Reflections of a Drafter, 43 Ohio State L.J. 537 (1982).

68. See Gunther, supra note 30, at 584 (noting that Ginsburg "put[ ] aside her major academic interest in comparative procedure" in order to do this work).

69. Ruth Bader Ginsburg, Remarks for the Celebration of 75 Years of Women's Enrollment at Columbia Law School, 102 Colum. L. Rev. I44I, I441 (2002) [hereinafter Ginsburg, Remarks for 75 Years]. 
direct way was by constitutional amendment: to secure adoption of the Equal Rights Amendment (ERA), proposed by Congress and sent to the States for ratification in $1972 .{ }^{70}$ The indirect way was to persuade the United States Supreme Court to radically alter its interpretation of the Equal Protection Clause to accord sex-based classifications strict, rather than merely rational, judicial scrutiny. The former route involved her in speeches, testimony, and publications in support of the ERA ratification effort between 1972 and 1980 . The latter route lay through litigation, which she undertook through the ACLU Women's Rights Project between 1972 and 1980. Neither avenue had yielded success by 1980, when Ginsburg left academia for the bench, but work on the first helped move the second along.

\section{A. The Equal Rights Amendment}

The Amendment was first introduced in Congress in $1923,{ }^{71}$ sponsored by Alice Paul and her National Women's Party in the hope of achieving the broad constitutional base of support for women's rights that the suffragists had expected to get from the Nineteenth Amendment. ${ }^{72}$ In 1972, Congresswoman Martha Griffiths, the principal House proponent of the Amendment, predicted that the ERA "will be ratified almost immediately." ${ }^{73}$ Between 1972 and 1978, Ruth made a number of speeches and wrote articles in support of the ERA. lllustrative of the articles are two published in the American Bar Association Joumal ${ }^{74}$ and one included in the first issue of the Harvard Women's Law Journal. ${ }^{75}$ In the first $\mathrm{ABA}$ piece, she traced the history of the proposed amendment, noting that the objections to its adoption voiced in 1973 were "solidly answered" during the 1920 s debate, ${ }^{76}$ but nonetheless answering them again $^{77}$ and going on to make the affirmative case for ratification. Her second $\mathrm{ABA}$ piece, published four years later as the time for ratification was running out, took the $\mathrm{ABA}$ to task for failing to carry out its 1974 undertaking "to play an active role in educating the public" about why "the E.R.A. is the way for a society that believes in the essential human dignity ... of each man and each woman." 78 Writing in the first issue of the Harvard Women's Law Journal a year later, her response to the critics was more succinct:

70. H.R.J. Res. 208, 92d Cong., 86 Stat. 1523 (1972).

71. S.J. Res. 21, 68th Cong. (1923).

72. See Carl N. Degler, At Odds: Women and the Family in America from the Revolution to the Present 359 (1980); Ruth Bader Ginsburg, The Need for the Equal Rights Amendment, 59 A.B.A. J. 1013, 1013 (1973) [hereinafter, Ginsburg, Need for ERA].

73. 117 Cong. Rec. 35,814-15 (daily ed. Oct. 12, 1971) (statement of Rep. Griffiths).

74. See Ruth Bader Ginsburg, Let's Have ERA as a Signal, 63 A.B.A. J. 70,70 (1977)

[hereinafter Ginsburg, Let's Have ERA]; Ginsburg, Need for ERA, supra note 72.

75. Ginsburg, ERA the Way, supra note 22.

76. Ginsburg, Need for ERA, supra note 72, at 1013.

77. Id. at 1017-18.

78. Ginsburg, Let's Have ERA, supra note 74 , at 73 . 
The ERA is not a "unisex" amendment. 1t does not stamp man and woman as one (the old common law did that); it does not label them the same; it does not require similarity in result, parity or proportional representation. It simply prohibits government from allocating rights, responsibilities or opportunities among individuals solely on the basis of sex. ${ }^{79}$

In the end, however, Representative Griffiths's prediction of swift passage proved inaccurate, and by 1978, Ruth was called upon to testify before both chambers of Congress in support of an extension of the initial 1979 ratification deadline for the ERA. Reflecting her expertise as a proceduralist, she first addressed four contested issues about the extension process. She argued that Congress had authority to extend the ratification period; that it could do so by a simple majority vote; that the President's signature was unnecessary to validate a Joint Resolution extending the deadline; and that extension of the time period would not, in itself, empower the states to rescind a prior ratification. ${ }^{80}$ Next, addressing the merits of extension, Ginsburg supported the need for additional time by stressing the Supreme Court's failure to act decisively in setting a new course for interpretation of the Equal Protection Clause dealing with sexbased classifications:

Arbitrary gender lines still clutter the lawbooks and regulations of the nation and states, the Supreme Court vacillates insecurely from one decision to the next, and is sometimes disarmed from reaching any decision, as it holds back doctrinal development and awaits the signal the Equal Rights Amendment would supply. ${ }^{81}$

Congress responded by extending the deadline until June 30 , $1982 .{ }^{82}$ In refashioning her arguments in 1979 for the Orgain Lecture at the University of Texas Law School, Ginsburg offered a milder, but still critical, assessment of the Court's equal protection precedents:

Since 1971, the Supreme Court has taken significant steps in a new direction, but generally, it has done so insecurely, with divided opinions, and without crisp doctrinal development. The longing of lower courts for firmer guidance was well expressed in a 1975 opinion by Judge Newcomer of the Eastern District of Pennsylvania: In dealing with recent High Court gender discrimination precedent, Judge Newcomer said, trial judges

79. Ginsburg, ERA the Way, supra note 22, at 21 (footnotes omitted).

80. Equal Rights Amendment Extension: Hearings on S.J. Res. 134 Before the Subcomm. on the Constitution of the Comm. on the Judiciary, 95th Cong. 265-71 (1978) (statement of Professor Ruth Bader Ginsburg, Columbia Law School).

81. Id. at 269.

82. H.R.J. Res. 638, 95th Cong. (1978), approved by the House of Representatives on August 15, 1978, 124 Cong. Rec. 26,193-203 (daily ed. Aug. 15, 1978), and by the Senate on October 6, 1978, 124 Cong. Rec. 34,314-15 (daily ed. Oct. 6, 1978). 
feel like players at "a shell game who [are] not absolutely sure there is a pea." 83

\section{B. Supreme Court Litigation}

Left modestly unsaid in this account was the fact that since 1971 Ginsburg and her colleagues at the ACLU Women's Rights Project had been doing their best to provide the Supreme Court with just such "crisp doctrinal development." Between 1972 and 1980 she filed briefs in nine of the major sex discrimination cases decided by the Court and personally argued six of them, winning all but one. She also filed amicus curiae briefs in fifteen related cases. Describing this work in these pages last year, Ginsburg said,

At the ACLU Women's Rights Project, which I assisted in launching early in 1972, and in the seminars I conducted at Columbia, work progressed on three fronts: We sought to advance, simultaneously, public understanding, legislative change, and change in judicial doctrine. ${ }^{84}$

Elaborating more recently on this strategy, she added,

Judges and legislators in the 1960s and at the start of the 1970s regarded differential treatment of men and women not as malign, but as operating benignly in women's favor. Women, they thought, had the best of all possible worlds. Women could work if they wished; they could stay home if they chose. They could avoid jury duty if they were so inclined, or they could serve if they elected to do so. They could escape military duty, or they could enlist. Our mission was to educate, along with the public, decisionmakers in the Nation's legislatures and courts. We tried to convey to them that something was wrong with their perception of the world. We sought to spark judges' and lawmakers' understanding that their own daughters and granddaughters could be disadvantaged by the way things were. ${ }^{85}$

Full accounts of this litigation have already been provided by Ginsburg $^{86}$ herself and by others, ${ }^{87}$ and accordingly I will not offer another

83. See Ruth Bader Ginsburg, Ratification of the Equal Rights Amendment: A Question of Time, 57 Tex. L. Rev. 919, 936 (1979) (footnotes omitted).

84. Ginsburg, Remarks for 75 Years, supra note 69.

85. Ruth Bader Ginsburg, Foreword to Symposium: Women, Justice and Authority, 14 Yale J.L. \& Feminism 213, 214-15 (2002).

86. See Ruth Bader Ginsburg, The Burger Court's Grapplings with Sex Discrimination, in The Burger Court: The Counter-Revolution That Wasn't 132, 132-33 (Vincent Blasi ed., 1983); Ruth Bader Ginsburg, Gender and the Constitution, 44 U. Cin. L. Rev. 1, 2 (1975); Ruth Bader Ginsburg, Gender in the Supreme Court: The 1973 and 1974 Terms, 1975 Sup. Ct. Rev. 1, 1; Ruth Bader Ginsburg, Gender in the Supreme Court: The 1976 Term, in Constitutional Government in America 217, 224 (Ronald K.L. Collins ed., 1980); Ginsburg, Remarks for 75 Years, supra note 69; Ruth Bader Ginsburg, Sex Equality and the Constitution, 52 Tul. L. Rev. 451, 474-75 (1978); Ruth Bader Ginsburg, Sexual Equality Under the Fourteenth and Equal Rights Amendments, 1979 Wash. U. L.Q. $161,161-62$.

87. See, e.g., Amy Leigh Campbell, Raising the Bar: Ruth Bader Ginsburg and the 
one here. Rather, 1 will refer to my own summary of Ruth's extraordinary contributions during these years on the occasion of her selection in 1999 by the American Lawyer as one of its "Lawyers of the Century":

The remarkable thing about this strategy, reexamined at the approach of the millennium, is how well it succeeded. Sex is not yet a "suspect" classification, but it receives heightened "intermediate" scrutiny as a direct result of Ginsburg's advocacy. Quite literally, it was her voice, raised in oral argument and reflected in the drafting of briefs, that shattered old stereotypes and opened new opportunities for both sexes. She built, and persuaded the [C]ourt to adopt, a new constitutional framework for analyzing the achievement of equality for women and men. 1n doing so, Ginsburg in large part created the intellectual foundations of the present law of sex discrimination. ${ }^{88}$

$* \quad * \quad *$

Ruth Bader Ginsburg began her academic career when there were less than twenty women law professors in the entire country. When she left in mid-career to become a federal judge, women were well established in law teaching. Like the fourteen early women law professors, Ginsburg was obliged to confront and deal with any misgivings that others-whether colleagues, students, or administrators-may have had about women teaching law. Ginsburg swept away all such misgivings by establishing a solid reputation for the painstaking accuracy of her work, the intellectual depth of her legal concepts, and the strength and clarity of her vision of women's rights as human rights. In her modest and unassuming way, she did this for herself almost as a matter of course. Looking back at her achievements today, it is clear that she established a pattern for all of us to follow. Although her work as a professor of law has ended, her distinguished career as a jurist continues and the powerful and persuasive sound of her voice still echoes through the universe of legal education.

ACLU Women's Rights Project, 11 Tex. J. Women \& L. 157, 158 (2002) (discussing Ginsburg's contributions to constitutional law as professor, lawyer, and women's rights advocate); Ruth B. Cowan, Women's Rights Through Litigation: An Examination of the American Civil Liberties Union Women's Rights Project, 1971-1976, 8 Colum. Hum. Rts. L. Rev. 373, 373-74 (1976) (discussing ACLU involvement in women's rights movement); Diana Gribbon Motz, Ruth Bader Ginsburg: Supreme Court Advocate 1971-1980 (unpublished manuscript, on file with the Columbia Law Review).

88. Herma Hill Kay, Ruth Bader Ginsburg, Am. Law., Dec. 1999, at 72, 72. 